\title{
Enzyme immunoassay for shrimp vibriosis
}

\author{
Y. L. Song ${ }^{1, *}$, S. P. Lee ${ }^{2}$, Y. T. Lin ${ }^{2}$, C. C. Chen ${ }^{1}$ \\ ${ }^{1}$ Department of Zoology, National Taiwan University, Taipei, Taiwan, Republic of China \\ ${ }^{2}$ Institute of Fisheries Science, National Taiwan University, Taipei, Taiwan, Republic of China
}

\begin{abstract}
In an effort to detect vibriosis caused by Vibrio vulnificus and V. harveyi in cultured shrimp in Taiwan, several enzyme immunoassays (EIA) were compared for sensitivity, reproducibility, time consumption, technical complexity and instrumentation requirements. For field applications, the indirect immunodot blot assay using avidin-biotin complex $(\mathrm{ABC})$ proved to be the best method for detection of subclinical vibriosis. This method can detect $10^{3}$ organisms per $100 \mu \mathrm{l}$ of hepatopancreas homogenates, and color results are clear-cut and available within $5.5 \mathrm{~h}$. These test kits are made specific by using monoclonal antibody reagents. Field surveys including shrimp from larval to adult stages are described in order to determine the feasibility of the $\mathrm{ABC}$ immunodot blot assay. This technology may help management to change their emphasis from disease control to health monitoring and thereby provide greater benefit to shrimp farmers.
\end{abstract}

\section{INTRODUCTION}

Since 1987, mass mortalities have occurred in shrimp intensively reared at different locations in Taiwan. Affected shrimp displayed nonspecific signs, including poor growth rate, anorexia, rough shell and milky musculature. The hepatopancreas showed an albinic and atrophic appearance. Bacterial infection was found in the hepatopancreas. Strains isolated from infected shrimp were characterized, and the dominant group was identified as Vibrios (Cheng 1989, Huang 1989). In order to detect vibriosis in cultured shrimp, several immunoassays were compared for their efficacy in field conditions. Ideally, the assay should be specific, sensitive, rapid, easy to perform, inexpensive and should not require special instrumentation. In this study, we have described an indirect immunodot blot assay using an avidin-biotin complex for the detection of shrimp pathogens in hepatopancreas homogenates.

Vibrio harveyi has been shown to be the dominant species among Vibrio spp. strains isolated from moribund tiger shrimp (Huang 1989). The same species has also been reported to cause mortalities in Penaeus monodon hatcheries in the Philippines (Lavilla-Pitogo 1988). Pathogenicity of $V$. harveyi for Penaeus monodon and Penaeus orientalis has been proven by artificial infection using both injection and water-borne

- Addressee for correspondence routes (Huang 1989, Liu et al. 1989, Lavilla-Pitogo et al. 1990). Vibrio vulnificus is an opportunistic pathogen indigenous to estuarine and marine environments year-round. Studies have shown that it can be isolated from seawater, sediment, plankton, shellfish, crabs (Tamplin et al. 1982) and eels (Tison et al. 1982). This organism was isolated from cultured shrimp and eels in Taiwan and was shown to be virulent not only for the original hosts but also for mice (Song et al. 1990). The human health risks of $V$. vulnificus are high, as a mortality rate of about $50 \%$ was seen in persons who were infected by this organism through food-borne exposure (Blake et al. 1979, Tacket et al. 1984, Morris \& Black 1985, Johnston et al. 1986). Based on their prevalence, pathogenicity and broad host range, $V$. harveyi and $V$. vulnificus were selected as the target organisms for screening in this study.

\section{MATERIALS AND METHODS}

Monoclonal antibodies. Because Vibrio vulnificus and V. harveyi are serologically cross-reactive, specific monoclonal antibodies (Mabs) were developed against each species. Monclonal antibodies D3A6, D3B3, C3D5 and $\mathrm{C} 1 \mathrm{C} 2$, raised against $V$. vulnificus, reacted with 10 $V$. vulnificus strains comprising 2 different biogroups (Tison et al. 1982). No cross-reactions were observed among 14 non- $V$. vulnificus strains comprising 12 
species and 5 genera (Table 1). The Mabs L4F4 and J3C4, raised against $V$. harveyi, reacted with the type strain ATCC14126 and 23 local strains of the same species. No cross-reactions were observed among 16 non- $V$. harveyi strains comprising 13 species and 5 genera (Table 1). The production and characterization of these Mabs have been detailed by Lin (1990) and Chen (1991). Isotypes of the immunoglobulins produced by each hybridoma were determined: D3A6, D3B3 and C1C2 were IgG1; C3D5 and L4F4 were IgG3; and J3C4 was IgG2a. The affinity of these Mabs for surface epitopes of $V$. vulnificus and $V$. harveyi was determined using the indirect fluorescent antibody technique (Lin et al. 1987). Because none of the individual Mabs raised against $V$. vulnificus could react with a commonly expressed surface epitope in all $\mathrm{V}$. vulnificus strains tested, Mabs D3A6, D3B3, C3D5 and $\mathrm{C} 1 \mathrm{C} 2$ were mixed and used in the 6 assays to avoid discrimination among strains. Using the additivity test (Friguet et al. 1983), Mabs L4F4 and J3C4 were determined to recognize different surface epitopes of $V$. harveyi. These 2 Mabs were therefore mixed and used in the 6 assays for detection of $V$. harveyi.
Rabbit anti-Vibrio sera. Immunogen of Vibrio vulnificus (strain TG617) was prepared by inactivation of whole cells at $65^{\circ} \mathrm{C}$ for $1 \mathrm{~h}$. The concentration of immunogen suspension was adjusted to $10^{9} \mathrm{ml}^{-1}$. Then it was mixed $1: 1$ with Freund's complete adjuvant and $1 \mathrm{ml}$ was injected into a New Zealand white rabbit subcutaneously between the scapulae. At 2 wk intervals, boosters were administered by injection of the immunogen mixed $1: 1$ in Freund's incomplete adjuvant. Final bleeding was done when agglutination titers of antiserum reached $1: 1024$. The antisera were lyophilized and stored at $-20^{\circ} \mathrm{C}$ for future use. Rabbit anti- $V$. harveyi (strain ATCC14126) serum was also prepared using the procedures described above. These polyclonal antisera were used only in the indirect sandwich enzyme immunoassay (EIA).

Preparation of antigens. Antigens were made using strains of $V$. vulnificus TG617 and $V$. harveyi ATCC14126 which were grown on tryptic soy broth (TSB, Difco) supplemented with $2.5 \% \mathrm{NaCl}$ and shaken for $18 \mathrm{~h}$ at $28^{\circ} \mathrm{C}$. Cells were inactivated overnight using $0.3 \%$ formalin. Bacterial cells were harvested by centrifugation at $11000 \times g$ for $25 \mathrm{~min}$ at $4{ }^{\circ} \mathrm{C}$, washed

Table 1. Specificity of monoclonal antibodies (Mabs) tested by indirect enzyme immunoassay (EIA). ND: not determined

\begin{tabular}{|c|c|c|c|c|c|c|}
\hline \multirow[t]{2}{*}{ Bacterial species and strain } & \multicolumn{6}{|c|}{ Indirect EIA reaction } \\
\hline & D3A6 & D3B3 & C3D5 & $\mathrm{C} 1 \mathrm{C} 2$ & L4F4 & $\mathrm{J} 3 \mathrm{C} 4$ \\
\hline \multicolumn{7}{|l|}{ Vibrio vulnificus } \\
\hline \multirow{5}{*}{$\begin{array}{ll}\text { Biogroup I. } & \text { ATCC27562 } \\
& \text { TG617 } \\
& \text { A2 } \\
& \text { 79-08-09 } \\
& \text { LSU11-3M-30 }\end{array}$} & + & - & - & - & - & - \\
\hline & + & + & + & + & ND & ND \\
\hline & - & + & + & + & ND & ND \\
\hline & - & - & + & - & ND & ND \\
\hline & + & + & + & + & ND & ND \\
\hline \multirow{5}{*}{$\begin{array}{ll}\text { Biogroup II. } & \text { ET-519 } \\
& \text { ET-7618 } \\
& \text { ES-7602 } \\
\text { KV-3 } \\
\text { HM1-1 }\end{array}$} & + & - & + & - & ND & ND \\
\hline & + & + & + & + & ND & ND \\
\hline & - & - & - & + & ND & ND \\
\hline & + & - & + & + & ND & ND \\
\hline & + & - & + & - & ND & ND \\
\hline \multirow{2}{*}{$\begin{aligned} \text { Vibrio harveyi ATCC14126 } & \\
& 23 \text { local strains }\end{aligned}$} & - & - & - & - & + & + \\
\hline & ND & ND & ND & ND & + & + \\
\hline Vibrio alginolyticus ATCC17749 & - & - & - & - & - & - \\
\hline Vibrio anguillarum serovar A & - & - & - & - & - & - \\
\hline serovar B & - & - & - & - & - & - \\
\hline serovar $\mathrm{C}$ & - & - & - & - & - & - \\
\hline Vibrio cholerae Inaba strain & ND & ND & ND & ND & - & - \\
\hline Ogawa strain & ND & ND & ND & ND & - & - \\
\hline Vibrio damsela ATCC 33539 & - & - & - & - & - & - \\
\hline Vibrio fluvialis ATCC 33809 & - & - & - & - & - & - \\
\hline Vibrio ordalii ATCC1669 & - & - & - & - & - & - \\
\hline Vibrio parahaemolyticus ATCC17802 & - & - & - & - & - & - \\
\hline Vibrio tubiashii ATCC19105 & - & - & - & - & - & - \\
\hline Aeromonas hydrophila ATCC7966 & ND & ND & ND & ND & - & - \\
\hline Aeromonas salmonicida & - & - & - & - & ND & ND \\
\hline Edwardsiella tarda $2 \mathrm{~K}$ & - & - & - & - & - & - \\
\hline Escherichia coli WP2 & - & - & - & - & - & - \\
\hline Pseudomonas fluorescence ATCC13525 & - & - & - & - & - & - \\
\hline
\end{tabular}


twice with PBS ( $\mathrm{pH} 7.0$ ) and resuspended to $10^{8} \mathrm{ml}^{-1}$. They were then frozen at $-20^{\circ} \mathrm{C}$ for future comparison of immunoassays. In order to compare the sensitivity of EIAs, 10-fold serial dilutions of antigens were prepared in carbonate coating buffer $(0.05 \mathrm{M}, \mathrm{pH} 9.6)$ or phosphate buffer (0.01 M, pH 7.0).

Comparison of immunoassays. The immunodot blot assay was compared with the indirect EIA and the indirect sandwich EIA (Fig. 1). Indirect EIA used in this study was carried out according to Austin et al. (1986). The indirect sandwich EIA technique was a modification of the procedures reported by Smith (1981). The immunodot blot assay used in this study was a partial modification of the methods described by Hawkes et al. (1982) and Hsu \& Leong (1985). The procedure for the immunodot blot is summarized as follows:

(1) Prepare the polyvinylidine difluoride (PVDF) membrane (Millipore) by rinsing with 100\% methanol to decrease its hydrophobicity.

(2) Rinse with nanopure water.

\section{$\underline{E I A}$}

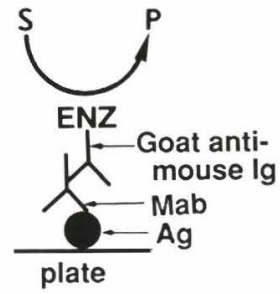

\section{SANDWICH EIA DOT BLOT}
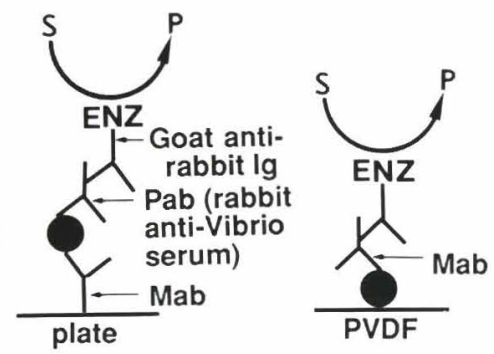

$A B C$

EIA

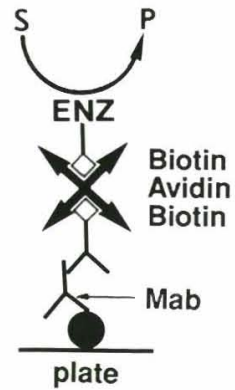

$A B C$ SANDWICH EIA

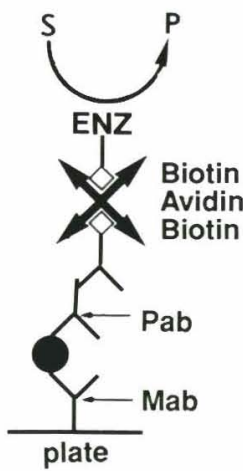

$A B C$ DOT BLOT
Fig. 1. Diagram of enzyme immunoassay (EIA) methods compared in this study: EIA, sandwich EIA, and immunodot blot assay. The 3 methods were also tested using avidin-biotin complex $(\mathrm{ABC})$ to increase sensitivity. S: substrate; P: product; ENZ: enzyme; Ig: immunoglobulin; Mab: monoclonal antibody; Ag: Vibrio vulnificus or $V$. harveyi cell; Pab: polyclonal antibody; PVDF: polyvinylidine difluoride membrane
(3) Immerse in a solution of phosphate buffered saline (PBS, 2 M, pH 7.0).

(4) Shake gently on a reciprocal shaker for $15 \mathrm{~min}$ at $25^{\circ} \mathrm{C}$.

(5) Rinse with nanopure water.

(6) Immediately place the membrane into a Hybrid Dot 96-well Filtration Manifold (BRL).

(7) Add $100 \mu \mathrm{l}$ of each of the serially diluted antigen preparations to the membrane surface of each well by the vacuum process.

(8) Remove the membrane from the Filtration Manifold.

(9) Immerse in a blocking solution of Gelatin-NET (Gelatin $0.25 \%, \mathrm{NaCl} 0.15 \mathrm{M}$, EDTA $5 \mathrm{mM}$, Tween-20 0.05\%, Tris base $50 \mathrm{mM}$ ) at room temperature and gently shake for $30 \mathrm{~min}$.

(10) Wash with a solution of PBS $0.02 \mathrm{M}, \mathrm{pH} 7.0$, with $0.05 \%$ Tween-20 (PBST) at room temperature for $15 \mathrm{~min}$.

(11) Dilute mouse ascitic fluids containing anti- $V$. vulnificus Mabs (D3A6, D3B3, C3D5 and C1C2) or anti- $V$. harveyi Mabs (L4F4 and J3C4) $20 \times$ and $200 \times$, respectively.

(12) Mount the Mabs onto the membrane and incubate $1 \mathrm{~h}$ at $37^{\circ} \mathrm{C}$.

(13) Wash the membrane twice with PBST.

(14) Transfer the membrane into a solution containing horseradish peroxidase conjugated goat antimouse Ig $(2000 \times$ dilution with Gelatin-NET, Pierce).

(15) Incubate at $37^{\circ} \mathrm{C}$ for $40 \mathrm{~min}$ and then at $4{ }^{\circ} \mathrm{C}$ for $20 \mathrm{~min}$.

(16) Rinse the membrane with PBST.

(17) Immerse the membrane in a freshly prepared $\mathrm{H}_{2} \mathrm{O}_{2}$ solution containing the insoluble 3-Amino9-Ethylcarbazole (AEC; Pierce) for color development.

(18) Shake for 15 to 30 min until red dots appear.

(19) Rinse the membrane with nanopure water.

(20) Store the membrane in the dark.

Application of avidin-biotin complex (ABC). In order to increase the sensitivity of immunoassays, avidin was used as a bridge to cross-link biotins which were conjugated to secondary antibodies and to the enzyme. Biotinylated goat-anti-mouse Ig $(220 \times$ dilution; Pierce) was used in both the indirect ELISA and the immunodot blot assay, while biotinylated goat-antirabbit Ig $(220 \times$ dilution; Pierce) was used in the indirect sandwich ELISA. The procedure for the application of the $\mathrm{ABC}$ is summarized as follows:

(1) Add the biotinylated secondary antibodies to the EIA plate or PVDF membrane processed as described above (steps 1 to 13).

(2) Incubate at $37^{\circ} \mathrm{C}$ for $1 \mathrm{~h}$.

(3) Wash the plate or membrane with PBST. 
(4) Add a freshly prepared solution containing avidin and biotinylated peroxidase to the plate or membrane.

(5) React at $37^{\circ} \mathrm{C}$ for $1 \mathrm{~h}$.

(6) Wash the plate or membrane with PBST.

(7) Add a $\mathrm{H}_{2} \mathrm{O}_{2}$ solution containing the color developer 2,2-azino-di-[3-ethyl-benzathiazoline sulfonate] diammonium salt (ABTS, used in EIA plate) or AEC (used in PVDF membrane).

(8) Observe with the naked eye or an ELISA reader (Emax, Molecular Devices) at a wavelength of $405 \mathrm{~nm}$.

The sensitivity (number of bacteria detected per $100 \mu \mathrm{l}$ of sample) was determined as the highest dilution of antigens in the well or dot in which visible color occurs. The reproducibility (trials of same sensitivity/number of trials), time requirement, technical complexity and need for special instrumentations in each assay were recorded.

Elimination of non-specific reaction in the EIAs using sodium dodecyl sulfate (SDS). It was understood that hepatopancreas peroxidase would contribute to the enzyme reaction in the EIAs when using peroxidase-conjugated antibody. Seven initial concentrations of SDS, $0.25,0.5,1.0,2.0,2.5,5$ and $10 \%$ in $0.85 \%$ $\mathrm{NaCl}$ solution, were tested for peroxidase inhibitory activity. The hepatopancreas from healthy shrimp was removed aseptically and homogenized in an equal volume of a sterile $0.85 \% \mathrm{NaCl}$ solution. Tissue debris was removed by sedimentation at $4{ }^{\circ} \mathrm{C}$ for $1 \mathrm{~h}$. Equal volumes of $100 \mu \mathrm{l}$ filter-sterilized supernatant $(0.22 \mu \mathrm{m}$, Millipore) and SDS solution were mixed. After reacting at room temperature for $15 \mathrm{~min}$, each mixture was bound to the membrane by the vacuum process. The membrane was then color-developed using the $\mathrm{ABC}$ immunodot blot assay.

To determine the influence of the added $10 \%$ SDS or other potentially inhibitory substances naturally present in the hepatopancreas on the reaction between bacteria harbored in hepatopancreas and antibody in the $\mathrm{ABC}$ immunodot blot assay, hepatopancreas of healthy shrimp was artificially inoculated with a known number of live Vibrio vulnificus. The hepatopancreas was then removed, homogenized and sedimented. The final number of bacteria in each $100 \mu \mathrm{l}$ supernatant fluid of hepatopancreas homogenate were from $10^{8}$ to $10^{2}$ cells (a logarithmic decrease). This supernatant fluid was mixed with an equal volume of $10 \%$ SDS solution. The mixture was bound to the PVDF membrane and the color developed with the $\mathrm{ABC}$ immunodot blot assay.

Feasibility of the $\mathrm{ABC}$ immunodot blot assay in a field survey. A total of 602 larval to adult shrimp, ranging from 0.6 to $23.5 \mathrm{~cm}$ in body length, were sampled from Tainan (Taiwan) hatcheries in July and
August 1990, and at Tungkang, Chiatung and Linyuan in April 1991. No mortalities or symptomatic diseases were present at the time of sampling. Bacterial isolations were made from the hepatopancreas on thiosulfate-citrate-bile salt-sucrose agar supplemented with $2 \% \mathrm{NaCl}$ (TCBS). Both green and yellow colonies on TCBS were subcultured on tryptic soy agar supplemented with $2.5 \% \mathrm{NaCl}$ (TSA). Each isolate on TSA was tested for susceptibility to both the vibriostatic agent, 2,4-diamino-6,7-diisopropyl pteridine phosphate $(0 / 129,150 \mu \mathrm{g}$; CPM, Taipei), and the antibiotic novobiocin (30 $\mathrm{gg}$; BBL, Hong Kong). Sensitive colonies were characterized according to Baumann et al. (1984). Meanwhile, the hepatopancreas of each individual was further processed to detect the presence of Vibrio vulnificus and V. harveyi. Equal volumes of $100 \mu \mathrm{l}$ supernatant from each hepatopancreas homogenate and $10 \%$ SDS solution were mixed and then tested using the $\mathrm{ABC}$ immunodot blot assay.

\section{RESULTS}

\section{Comparison of immunoassays}

The comparative ability of the 6 different immunoassays to detect the potential shrimp pathogens Vibrio vulnificus and $V$. harveyi was examined (Table 2). It was found that the sensitivity of the indirect EIA was limited to $10^{5}$ bacteria per $100 \mu \mathrm{l}$ of hepatopancreas homogenate. Enhancement of sensitivity by 1 order of magnitude was achieved in 3 of 5 trials through the use of $\mathrm{ABC}$. Sandwich EIA, with or without the application of $\mathrm{ABC}$, had a sensitivity of $10^{3}$ bacteria per $100 \mu \mathrm{l}$ of hepatopancreas homogenate in at least $50 \%$ of the trials. Instead of a 96 -well polystyrene microtiter plate, the PVDF membrane was used as the solid phase in the indirect immunodot blot assay. Owing to the high affinity of proteins for the PVDF membrane, a 10-fold increase in sensitivity was obtained in the indirect immunodot blot assay compared with the indirect EIA. The indirect immunodot blot assay using $A B C$, however, was shown to be the most sensitive, detecting 100 organisms per $100 \mu \mathrm{l}$ of hepatopancreas homogenate (Fig. 2). This result was reproducible, color development was clear and distinguishable with the naked eye with no special instrument required.

Influence of SDS and other potential inhibitory substances in the hepatopancreas on the $\mathrm{ABC}$ immunodot blot assay

A $10 \%$ initial concentration SDS $15 \%$ in the final hepatopancreas extract) was shown to be high enough 
Table 2. Comparison of immunoassays for shrimp vibriosis. EIA: enzyme immunoassay; ABC: avidin-biotin complex; R: ELISA reader; E: naked eye

\begin{tabular}{|c|c|c|c|c|c|c|c|}
\hline Indirect assay & $\mathrm{ABC}$ & Sensitivity $^{\mathrm{a}}$ & $\begin{array}{l}\text { Reproduci- } \\
\text { bility }^{\mathrm{b}}\end{array}$ & $\begin{array}{l}\text { Technical } \\
\text { steps }\end{array}$ & $\begin{array}{l}\text { Back- } \\
\text { ground }\end{array}$ & Reading & $\begin{array}{l}\text { Time } \\
\text { (h) }\end{array}$ \\
\hline \multirow[t]{2}{*}{ EIA } & - & $10^{5}$ & $6 / 7$ & 5 & low & $\mathrm{R} / \mathrm{E}$ & 4.5 \\
\hline & + & $10^{4}$ & $3 / 5$ & 6 & high & $R / E$ & 5.5 \\
\hline \multirow[t]{2}{*}{ Sandwich EIA } & - & $10^{3}$ & $5 / 8$ & 6 & moderate & $R / E$ & 5.5 \\
\hline & + & $10^{3}$ & $2 / 4$ & 7 & high & $\mathrm{R} / \mathrm{E}$ & 6.5 \\
\hline \multirow[t]{2}{*}{ Immunodot BLOT } & - & $10^{4}$ & $4 / 5$ & 5 & low & E & 4.0 \\
\hline & + & $10^{2}$ & $6 / 6$ & 6 & low & $\mathrm{E}$ & 5.5 \\
\hline
\end{tabular}

Fig. 2. Sensitivity of ABC immunodot blot as-

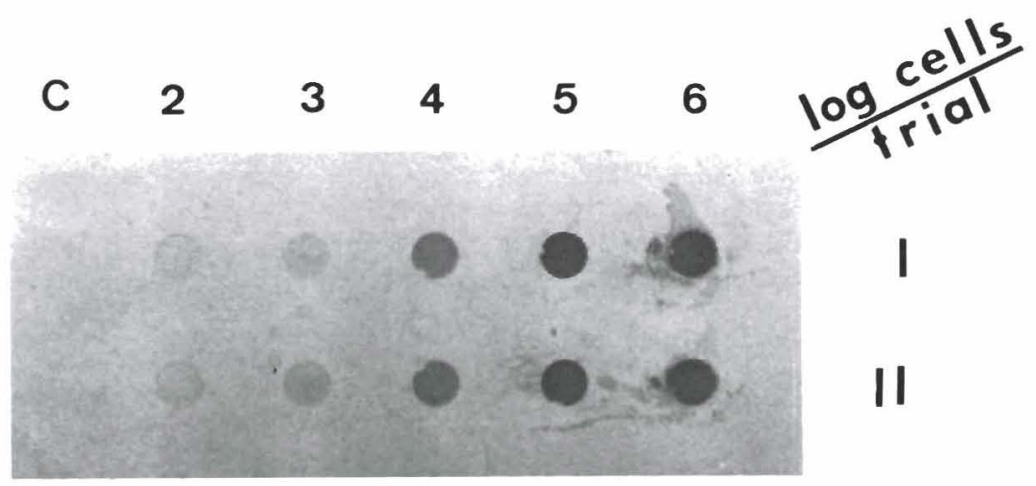
say for Vibrio vulnificus

Feasibility of $\mathrm{ABC}$ immunodot blot assay in the field survey

Vibrio strains isolated from hepatopancreas of shrimp collected in the field survey were characterized (Table 3). Both Vibrio vulnificus and V. harveyi strains were Gram-negative rods, could grow at $40^{\circ} \mathrm{C}$ and utilize chitin, cellobiose, casein and tyrosine, and were lysine decarboxylase positive. Of the $447 \mathrm{~V}$. harveyi strains isolated 78 were luminous while $39 \mathrm{~V}$. vulnificus strains and the remaining $V$. harveyi strains were non-
Fig. 3. Effect of sodium dodecyl sulfate on hepatopancreas peroxidase in the $A B C$ immunodot blot assay
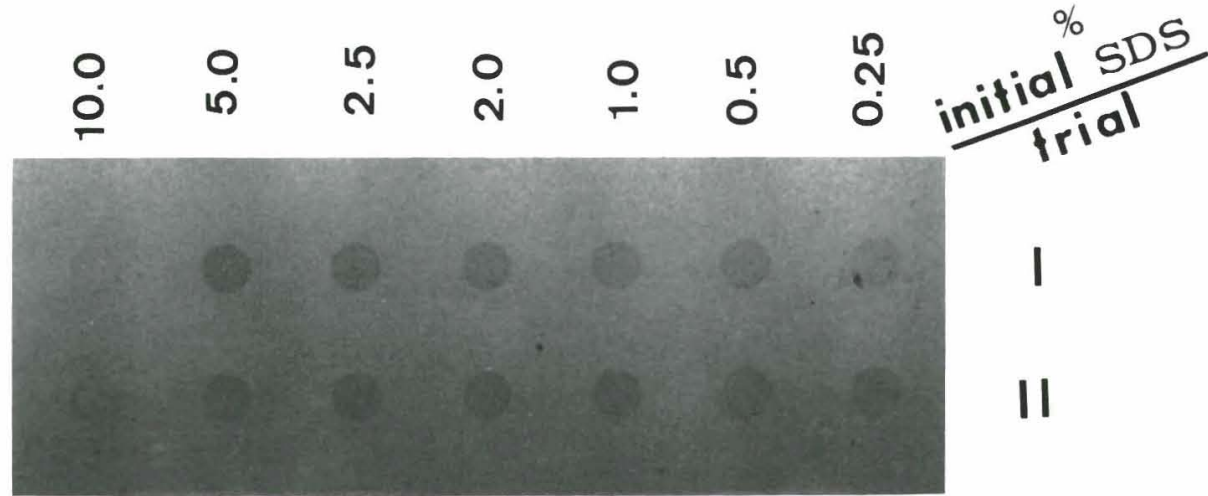


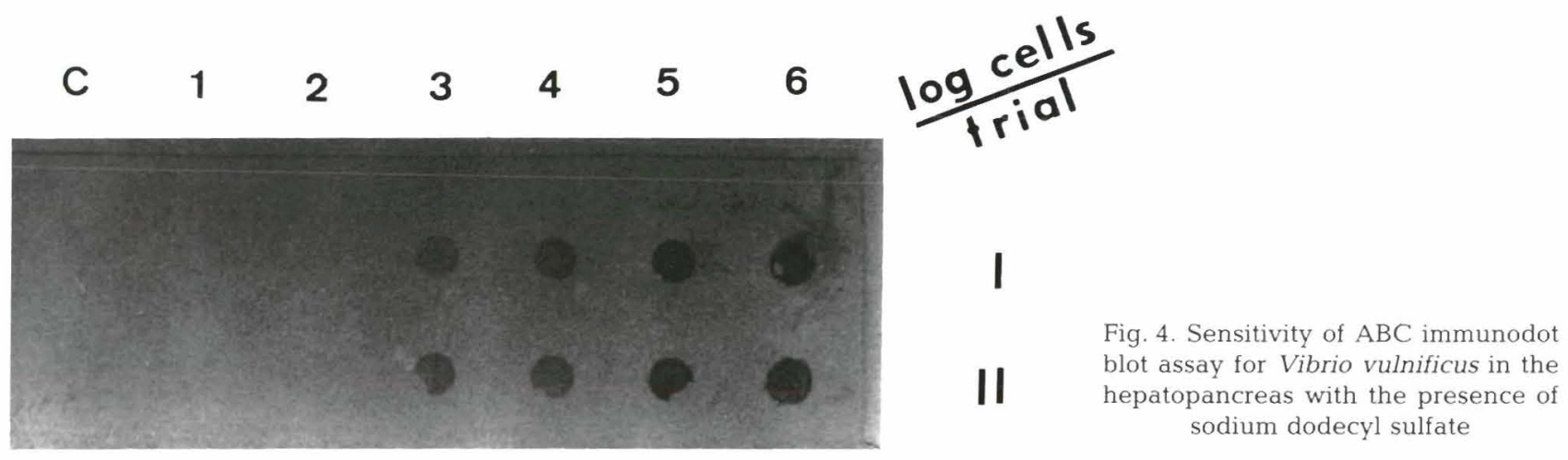

Table 3. Differential characteristics of Vibrio vulnificus and V. harveyi isolated in the field survey. TCBS: thiosulfate-citrate-bile salt-sucrose; ONPG: o-nitrophenyl-B-D-galactopyranoside

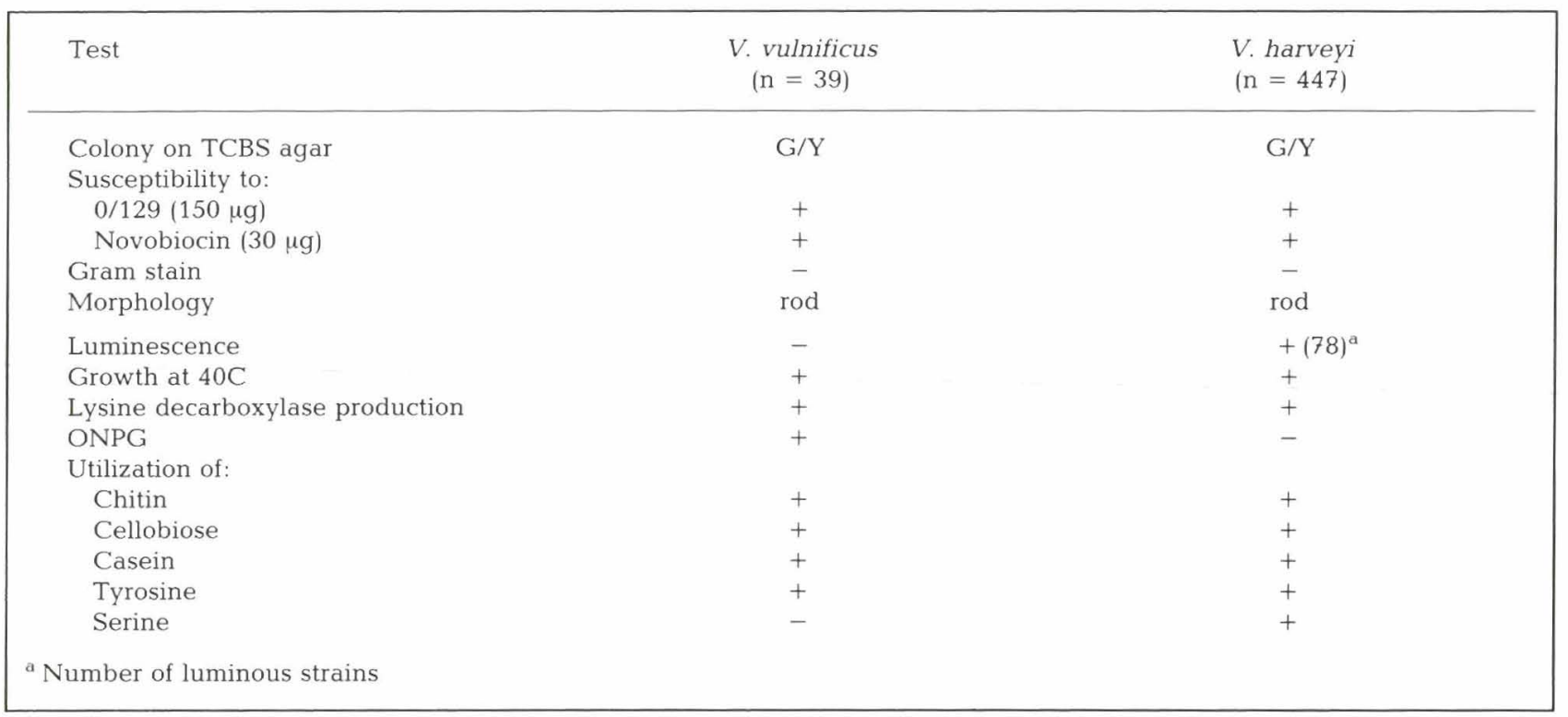

luminous. $V$. harveyi strains utilized serine, but $V$. vulnificus strains did not. $V$. vulnificus strains were able to decompose ONPG, but $V$. harveyi strains could not.

Among the 602 shrimp collected, 379 shrimp were shown to harbor Vibrio spp. Hepatopancreas homogenates were checked for the presence of Vibrio vulnificus and $V$. harveyi using both classical bacterial identification and the $\mathrm{ABC}$ immunodot blot assay. The proportion of shrimp harboring $V$. vulnificus or $V$. harveyi in each collection remained identical or increased when the $\mathrm{ABC}$ immunodot blot assay was used (Table 4).

\section{DISCUSSION}

The immunodot blot assay without application of $\mathrm{ABC}$ proved to be superior to other assays tested in relation to reproducibility, technical complexity, time consumption and special instrumentation requirements. However, the detection limit may be too low to diagnose, for example, the Vibrio vulnificus in oysters, where concentrations ranged from $10^{3}$ to $10^{5}$ bacteria $\mathrm{g}^{-1}$ of tissue homogenate (Bryant et al. 1987, Kaysner et al. 1989). Development of a diagnostic kit to be used not only for symptomatic infections but also for earlyinfected or subclinical carriers would be very useful. In the field survey, the application of the PVDF membrane with the aid of the Hybrid Dot 96-well Filtration Manifold allowed diagnosis of a large number of samples. Visual interpretation of the results will make it practical for future use in hatcheries. Basic laboratory facilities, however, including a vacuum line for filtration, are needed and there are problems of technical complexity and high cost to be solved.

Bacterial isolation and characterization confirmed the accuracy of the $\mathrm{ABC}$ immunodot blot assay, demon- 
Table 4. Diagnosis of shrimp harboring Vibrio spp., V. vulnificus and V. harveyi using bacterial isolation (BI) and the indirect ABC immunodot blot assay (IDB)

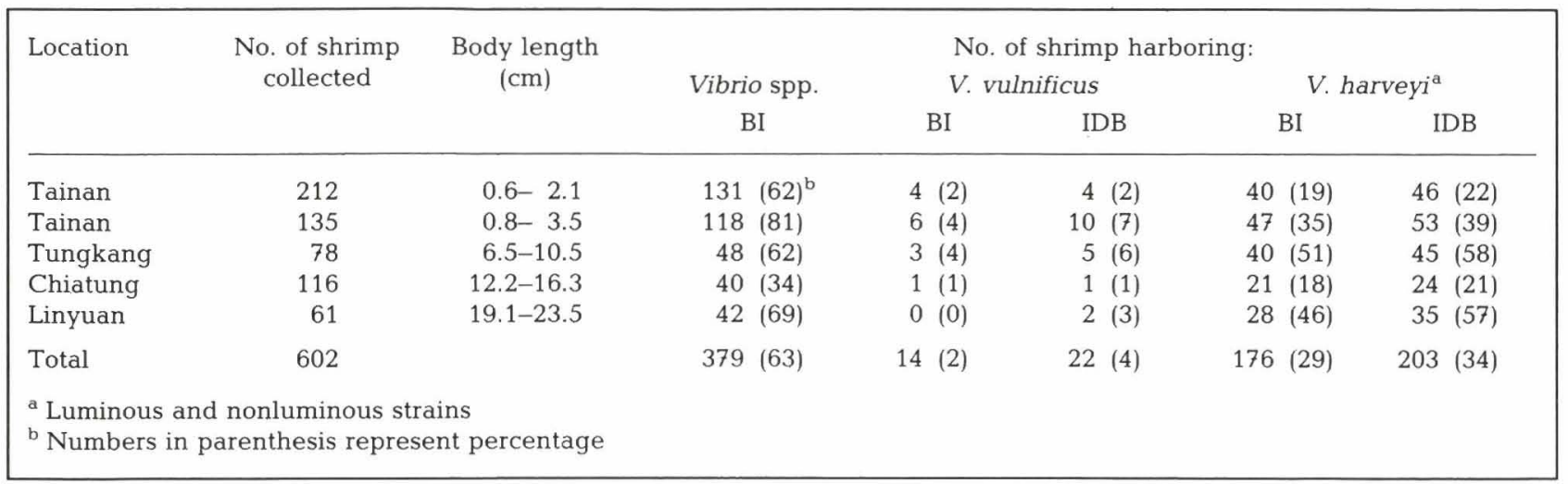

strating that carriers of Vibrio harveyi and V. vulnificus, detected by bacterial isolation, were also positive in the $\mathrm{ABC}$ immunodot blot assay. The opposite, however, was not true, suggesting that bacterial isolation from the hepatopancreas on TCBS agar may not be as sensitive as the $\mathrm{ABC}$ immunodot blot assay from organ homogenates. This may be because only viable bacteria can be cultured whereas both viable and dead cells are detected in the $\mathrm{ABC}$ immunodot blot assay. The presence of SDS may not only eliminate the interference of tissue peroxidase but also disrupt the bacterial cells in the hepatopancreas. Attachment of bacterial fragments of the PVDF membrane should be greater than that of intact cells; thus a higher dose of antigens would be bound on the solid phase and better sensitivity obtained.

Because the immunodot blot assay has the advantage of detecting both culturable and non-culturable cells, handling between collection and processing to ensure organisms' viability (Oliver 1981) is less critical. Besides, rapid identification tests will probably improve ecological and clinical investigations of shrimp vibrios. These advances will reduce the need for many biochemical tests. With improvements in direct identification techniques using Mabs, the need for culture techniques should be substantially reduced.

Shrimp from larvae to adult were screened for the presence of Vibrio vulnificus and $V$. harveyi. Results showed that shrimp of all stages carried these vibrios. This discovery ruled out the previous conjecture that shrimp in the larval stage were more easily susceptible to Vibrio infection, and the results are consistent with observations from Malaysian shrimp ponds, where mortalities occurred throughout the year and were equally likely to occur in any pond (Anderson \& Shariff 1987).

Only $2 \%$ (assayed with the method of bacterial isolation) to $4 \%$ (assayed with the method of $\mathrm{ABC}$ immunodot blot) of the shrimp harbored Vibrio vulnificus. Mortalities or symptomatic disease were not present at the time of sampling, suggesting that $V$. vulnificus is an opportunistic pathogen. However, the positive chitinoclastic activity of our isolates suggests a mechanism for bacterial penetration of the shrimp exoskeleton. Baumann et al. (1980) showed that all pathogenic Vibrio species elaborate an extracellular chitinase. Furthermore, even if $V$. vulnificus is only present opportunistically, its virulence to many hosts including humans should be noted. This study showed that $29 \%$ (bacterial isolation) to $34 \%$ (ABC immunodot blot) of the shrimp harbored $V$. harveyi, suggesting that $V$. harveyi is not pathogenic but rather endemic and possibly becomes pathogenic when shrimp are stressed by other factors. However, these results should not be taken to mean that no other virulent organisms were involved in the shrimp epidemics. While $63 \%$ of the shrimp were found to be carriers of genus Vibrio, only $31 \%(2+29 \%)$ of the shrimp were carriers of $V$. vulnificus and $V$. harveyi. Therefore, other species could be involved in mortalities, including $V$. damsela (Song et al. 1992), V. nereis, V. tubiashi, and V. anguillarum, etc. (Huang 1989). Mixed infection might also account for the shrimp epidemics. In any case, the ABC immunodot blot assay can be an effective tool to monitor for the presence of Vibrio spp. and to detect increases prior to symptomatology and mass mortalities which result in serious economic losses to shrimp farmers.

Acknowledgements. The authors thank Dr Y. L. Hsu, Institute of Zoology, Academia Sinica, for providing the opportunity to learn immunodot assay techniques. They also express appreciation to Dr C. P. Lin, Department of Plant Pathology, National Taiwan University, for providing the fluorescent microscope. This research was financially supported by the National Science Council, under Grant No. 78-0418-B-002-10H and the Council of Agriculture, under Grant No. 80 AD-7.1-F$10(3)$. 


\section{LITERATURE CITED}

Anderson, I. G., Shariff, M. (1987). Mortalities of juvenile shrimp, Penaeus monodon, associated with Penaeus monodon baculovirus, cytoplasmic reo-like virus, and rickettsial and bacterial infections, from Malaysian brackishwater ponds. Asian Fish. Sci. 1: 47-64

Austin, B., Bishop, I., Gray, C., Watt, B., Dawes, J. (1986). Monoclonal antibody-based enzyme-linked immunosorbent assays for the rapid diagnosis of clinical cases of enteric redmouth and furunculosis in fish farm. J. Fish Dis. 9: 469-474

Baumann, P., Baumann, L., Bang, S. S., Woolkalis, M. J. (1980). Reevaluation of the taxonomy of Vibrio, Beneckea and Photobacterium: abolition of the genus Beneckea. Curr. Microbiol. 4: 127-132

Baumann, P., Furniss, A. L., Lee, J. V. (1984). The genus Vibrio. In: Krieg, N. R., Holt, J. G. (eds.) Bergey's Manual of systematic bacteriology, Vol. 1. Williams and Wilkins, Baltimore, p. 518-538

Bryant, R. G., Jarvis, J., Janda, J. M. (1987). Use of sodium dodecyl sulfate-polymyxin B-sucrose medium for isolation of Vibrio vulnificus from shellfish. Appl. environ. Microbiol. 53: 1556-1559

Blake, P. A., Merson, M. H., Weaver, R. E., Hollis, D. G., Heublein, P. C. (1979). Disease caused by a marine Vibrio. Clinical characteristics and epidemiology. N. Engl. J. Med. 300: $1-5$

Chen, C. C. (1991). Characterization of monoclonal antibodies against Vibrio harveyi. Summer report, Dept of Zoology, National Taiwan Univ., Taipei

Friguet, B., Djavadi-Chaniance, L., Pages, J., Bussard, A., Goldberg, M. (1983). A convenient enzyme-linked immunosorbent assay for testing whether monoclonal antibodies recognize the same antigenic site. Application to hybridomas specific for the B2-subunit of Escherichia coli tryptophan synthase. J. immun. Method. 60: 351-358

Hawkes, R., Niday, E., Gordon, J. (1982). A dot immunobinding assay for monoclonal and other antibodies. Analyt. Biochem. 119: 142-147

Hsu, Y. L., Leong, J. C. (1985). A comparison of detection methods for infectious haematopoietic necrosis virus. $\mathrm{J}$. Fish Dis. 8: 1-12

Huang, S. L. (1989). Bacterial infection in cuitured black tiger prawn (Penaeus monodon). Master's thesis, National Taiwan Univ., Taipei

Johnston, J. M., Becker, S. F., McFarland, L. M. (1986). Gastroenteritis in patients with stool isolates of Vibrio vulnificus. Am. J. Med. 80: 336-338

Responsible Subject Editor: J. E. Stewart, Dartmouth, N.S., Canada
Kaysner, C. A., Tamplin, M. L., Wekell, M. M., Stott, R. F., Colburn, K. G. (1989). Survival of Vibrio vulnificus in shellstock and shucked oysters (Crassostrea gigas and Crassostrea virginica) and effects of isolation medium on recovery. Appl. environ. Microbiol. 55: 3072-3079

Lavilla-Pitogo, C. R. (1988). Isolation and identification of luminous bacteria causing mortalities in Panaeus monodon hatcheries in panay. SEAFDEC (Southeast Asian Fisheries Development Center, Philippines) Asia Aquaculture 10: 9

Lavilla-Pitogo, C. R., Baticados, M. C. L., Cruz-Lacierda, E. R., De la Pena, L. D. (1990). Occurrence of luminous bacterial disease of Panaeus monodon larvae in the Philippines. Aquaculture 91: 1-13

Lin, C. P., Chen, T. A., Wells, J. M., van der Zwet, T. (1987). Identification and detection of Erwinia amylovora with monoclonal antibodies, Phytopathology 77 : 376-380

Lin, Y. C. (1990). Characterization of monoclonal antibodies against Vibrio vulnificus. Master's thesis, National Taiwan Univ., Taipei

Liu, T. C., Su, K. C., Huang, W. C. (1989). Pathogenic and biological studies of bacteria isolated from Chinese penaeid (Penaeid orientalis) infected with red-leg disease. Fujian Fish. 2: 1-3

Morris, J. G. Jr, Black, R. E. (1985). Cholera and other vibrioses in the United States. N. Engl. J. Med. 312: 343-350

Oliver, J. D. (1981). Lethal cold stress of Vibrio vulnificus in oysters. Appl. environ. Microbiol. 41: 710-717

Song, Y. L., Cheng, W., Shen, C. H., Ou, Y. C., Sung, H. H. (1990). Occurrence of Vibrio vulnificus infections in cultured shrimp and eel in Taiwan. Proc. ROC-Japan Symp. on Fish Dis., National Science Council, Taipei, p. $172-179$

Song, Y. L., Cheng, W., Wang, C. H. (1992). Isolation and characterization of Vibrio damsela infections for cultured shrimp in Taiwan. J. Invertebr. Pathol. (in press)

Smith, P. D. (1981). Enzyme-linked immunosorbent assay (ELISA) for detection of Aeromonas salmonicida in diseased fish tissue. In: International symposium on fish biologics, serodiagnostics and vaccines, Leetown, W. Va. Develop. biol. standard, 49, S. Karger, Basel, p. 97-100

Tacket, C. O., Brenner, F., Blake, P. A. (1984). Clinical features and an epidemiological study of Vibrio vulnificus infections. J. infect. Dis. 149: 558-561

Tamplin, M. L., Rodrick, G. E., Blake, N. E., Cuba, T. (1982). Isolation and characterization of Vibrio vulnificus from two Florida estuaries. Appl. environ. Microbiol. 44: 1466-1470

Tison, D. L., Nishibuchi, M., Greenwood, J. D., Seidler, R. J. (1982). Vibrio vulnificus biogroup 2: new biogroup pathogenic for eels. Appl. environ. Microbiol. 44: 640-646

Manuscript first received: August 8, 1991

Revised version accepted: June 30, 1992 